\title{
Characteristics of Isolated Starch Granules of Two Sorghum Varieties
}

\author{
Sorour, M.A. ${ }^{1}$, A. E. Mehanni ${ }^{1}$, E. M. Taha ${ }^{2}$ and A. K. Rashwan ${ }^{2}$ \\ ${ }^{1}$ Food Science and Nutrition Dept. Faculty of Agriculture, Sohag University, Sohag, Egypt. \\ ${ }^{2}$ Food Science and Dairy Dept. Faculty of Agriculture, South Valley University, Qena, Egypt.
}

\begin{abstract}
Sorghum, like other cereals, is a good source of starch, that reached to about 60$80 \%$ of kernels which had an brilliant potential for global industrial claims. In this study, starch had been isolated from tow sorghum varieties (low tannin; Giza 15 and high tannin; Assiut 14) using different extraction procedures (boiling in water and in alkaline media and soaking in alkaline media).Starch yield, gel consistencies, degree of syneresis, gelatinization temperature range, shape and size of starch granules, and starch color had been assayed for the isolated starch. The results revealed that Giza 15 had higher starch yield for all extraction procedures, gels made from (Giza 15) was thinnest than that made from (Assiut 14), the degree of syneresis increased by way of starch gel decrease. Results also showed that neither significant difference of gelatinization temperature between white and pigmented sorghum starches nor between the extractions procedure for the pigmented starch was noted. Giza 15 starch had the highest $L^{*}$ value (91.3) however Assiut 14 variety gave a little darker starch. The pigmented sorghum starch appearance was comparable to that of white variety. The starch granules were mostly spherical and polygonal, with indentations and pores on the surface radial, tube-like channels of granules penetrate from the external surface into a cavity at the hilum, starch granule size of Giza 15 exhibited not significantly difference for larger size compared to that of Assiut 14 extracted using different extraction procedures. The result concluded that the starch isolated from pigmented sorghum grains using the alkaline procedure was comparable to white starches; thereby it could be replace it in the food industry fields
\end{abstract}

Key words: Starch granules isolation, Sorghum varieties. Starch characteristics

\section{INTRODUCTION}

Sorghum (Sorghum bicolor L. Moench), typically cultivated crosswise the world in the warm climatic regions, is quantitatively the world's fifth largest important cereal grain after wheat, maize, rice, and barley (Taylor et al., 2006).

*Corresponding author: EmanTaha,

Email: e.taha@agr.svu.edu.eg

Received: April 20, 2019;

Accepted: May 18, 2019;

Published: May 20, 2019.
However, with decreasing water supplies, and increasing world population it is forecasted as an important future crop. Sorghum is classified as sorghum, tannin sorghum, white sorghum, and mixed sorghum (FGIS-GIPSA, 2006).

Sorghum can practically be characterized according to end use. Sorghum, like other cereals, is rich in starch, that reaching from $68-75 \%$ depending upon cultivar, region and climatic conditions (Subramanian et al., 1994; Singh et al., 2009). Sorghum starch has brilliant use for industrial applications (Zhang et al., 2010) and using 
excess sorghum is by way of producing starch and starch based sweeteners.

Starch granules consist of amylose (20$30 \%)$ and amylopectin (70-80\%). The physicochemical and functional properties of starch normally are a clear outcome of the interaction between starch molecules and other food components and physical prearrangement of amylose and amylopectin and as well which affect the quality of starch and the starch based products (Boudries et al., 2009).

Sorghum starch occurs in a extremely arranged form inside the granules. Starch granules in the hard corneous type endosperm are strongly bound in a firm protein matrix, while the starch granules are lightly spaced and lightly surrounded by protein bodies in the floury soft endosperm (Turner, 2004). Morphology of starch granules such as shape and size are features of their botanical origin (Kaur et al., 2007). Environmental temperature is seriously effect on the starch composition, amylopectin structure and gelatinization properties (Matsuki et al., 2003). Starch granule size, amylose/amylopectin ratio as well as gelatinization temperature has effect on the physiochemical properties of the starch that subsequently influence the quality of starch and starch based products. Furthermore, they are important to starch potential purposes.

Little interest was associated to sorghum starches and still less to the starch of sorghum growing in the hyper arid areas of Egypt. Sorghum starch had an excellent potential for global industrial applications. Therefore, further characterization is required to better understanding the difference of physiochemical and functional properties of starch from different sorghum varieties. This article focuses on morphological, thermal properties and content of isolated starch from white and red sorghum grains cultivated under southern conditions of Egypt.

\section{Martials and methods}

\subsection{Materials:-}

Sorghum cultivars (Sorghum bicolor L. Moench); low tannin sorghum (Giza 15) and high tannin sorghum (Assiut 14) samples were obtained from Agriculture Research Center, Shandawel, Sohag, Egypt, and Season 2013.

\subsection{Methods}

\subsubsection{Starch isolation}

Starch was isolated from sorghum grain by steeping and wet milling steps according to Sira and Amaiz (2004).

\subsubsection{Starch isolation from white sorghum samples (Giza 15 ):}

$100 \mathrm{~g}$ of white sorghum grains were suspended in $0.25 \% \mathrm{NaOH}$ (Method A) solution (200 mL). After overnight, steeping the grain was washed until neutral $\mathrm{pH}$. The steeped grains were ready for wet milling.

\subsubsection{Starch isolation from} pigmented sorghum samples (Assiut 14):

For pigmented sorghum (Assiut 14) two different extraction procedures were used for starch isolation from sorghum grains as follow:

2.2.1.2.1. Brown sorghum samples were treated with sodium hypochlorite in alkaline medium (steeping procedure) prior to wet milling. The media for the steeping phase were composed as follows (Table 1), $5.25 \%$ sodium hypochlorite and $10.7 \%$ potassium hydroxide (Method 1A), 5.25\% sodium hypochlorite and $5.35 \%$ potassium hydroxide (Method 1B), and $5.25 \%$ of sodium hypochlorite without $\mathrm{KOH}$ (Method 1C). 
Sorour et al., : SVU-International Journal of Agricultural Sciences, 1 (1): 56-69, 2019

Table (1) Alkaline medium of treatment sorghum grains.

\begin{tabular}{clc}
\hline $\begin{array}{c}\text { Sorghum } \\
\text { Cultivars }\end{array}$ & \multicolumn{1}{c}{ Alkaline medium } & Methods \\
\hline & Heating with water & Control 1 \\
& Heating with $\mathrm{KOH} 10.7 \%+\mathrm{NaOCL} 5.25 \%$ & $1 \mathrm{~A}$ \\
& Heating with $\mathrm{KOH} 5.35 \%+\mathrm{NaOCL} 5.25 \%$ & $1 \mathrm{~B}$ \\
\multirow{5}{*}{ Assiut 14 } & Heating with $\mathrm{NaOCL} 5.25 \%$ & $1 \mathrm{C}$ \\
& Soaking 2days in water & Control 2 \\
& Soaking 2days in $\mathrm{NaOH} 0.25 \%+\mathrm{NaHSO}_{3} 0.025 \%$ & $2 \mathrm{~A}$ \\
& Soaking 2days in $\mathrm{NaOH} 0.25 \%+\mathrm{NaHSO}_{3} 0.05 \%$ & $2 \mathrm{~B}$ \\
& Soaking 2days in $\mathrm{NaOH} 0.25 \%+\mathrm{NaHSO}_{3} 0.1 \%$ & $2 \mathrm{C}$ \\
\multirow{2}{*}{ Giza 15 } & Soaking in water all night & Control A \\
& Soaking in NaOH 0.25\% all night & A \\
\hline
\end{tabular}

Table (2) Effect of different extraction alkaline medium on yield of sorghum starch.

\begin{tabular}{|c|c|c|}
\hline $\begin{array}{l}\text { Sorghum } \\
\text { Cultivars }\end{array}$ & Starch isolation procedure & Starch yield $(\%)$ \\
\hline \multirow{8}{*}{ Assiut 14} & Boiling in water & 22.39 \\
\hline & Boiling in $\mathrm{KOH} 10.7 \%+\mathrm{NaOCl} 5.25 \%$ & 26.81 \\
\hline & Boiling in $\mathrm{KOH} 5.35 \%+\mathrm{NaOCl} 5.25 \%$ & 20.56 \\
\hline & Boiling in $\mathrm{NaOCl} 5.25 \%$ & 21.69 \\
\hline & Soaking in water for 2 days & 33.47 \\
\hline & Soaking in $\mathrm{NaOH} 0.25 \%+\mathrm{NaHSO}_{3} 0.025 \%$ for 2 days & 28.91 \\
\hline & Soaking in $\mathrm{NaOH} 0.25 \%+\mathrm{NaHSO}_{3} 0.05 \%$ for 2 days & 20.34 \\
\hline & Soaking in $\mathrm{NaOH} 0.25 \%+\mathrm{NaHSO}_{3} 0.1 \%$ for 2 days & 19.88 \\
\hline \multirow{2}{*}{ Giza 15} & Soaking in water overnight & 39.24 \\
\hline & Soaking in $\mathrm{NaOH} 0.25 \%$ overnight & 37.57 \\
\hline
\end{tabular}

2.2.1.2.2. Three batches of $100 \mathrm{~g}$ each were steeped in $200 \mathrm{~mL}$ of sodium bisulfite in alkaline medium at different concentrations. Steeping medium consisted of $0.25 \% \mathrm{w} / \mathrm{v} \mathrm{NaOH}$, for Methods $2 \mathrm{~A}, 2 \mathrm{~B}$ and $2 \mathrm{C}, \mathrm{NaHSO}_{3}$ was added to give final sulfur concentrations of $0.025,0.05$ and $0.1 \%$, respectively. All samples were wet milled after steeping for 2 days.

\subsubsection{Wet milling procedures:}

Wet grains milling were done in a blender home mill (Moulinex blenders) for $5 \mathrm{~min}$, the resulting was filter by cheese cloth, the starch isolated by gravity and excess water was get ride. The resulted starch was dried overnight at $45^{\circ} \mathrm{C}$ (Perez et al., 1993). 


\subsubsection{Sorghum starch yield determination:}

Sorghum starch yield were calculated according to the following equation (Ratnayake et al., 2007):

$$
\text { Extracted starch (g) }
$$

Starch yield $\%=\longrightarrow \times 100$

Dry weight of used sorghum $(\mathrm{g})$

\subsubsection{Determination of gel consistence:}

Gel consistence was measured according to Chandrashekar and Kirleis (1988).

\subsubsection{Determination of the syneresis degree:}

The syneresis degree of starch gels was determined as described by Yang et al. (1980).

\subsubsection{Determination of gelatinization temperatures range:}

Gelatinization temperature range of starch was determined using a light microscopes described by Hoseney (1994).

\subsubsection{Determination of color:}

The color was determined using the Hunter L, a, b method using Lovibond glasses calibrated in accordance with Giese (2000).The surface color characteristics of sorghum starch were measured by Colored Differences Meter (CDM) (model color TecPCM, U.S.A) using different color parameters ("L", "a", "b") (Beta et al., 2001).

\subsubsection{Determination of shape and size of starch granules:}

Size and shape of resulted starch granules were examined as described by Hoseney et al. (1981) using light microscope.

\section{Results}

\subsection{Properties of starch isolated by different alkaline medium:-}

\subsubsection{Starch yield:}

Starch yield obtained from Assiut 14 and Giza 15 sorghum samples are shown in Table 2 and Fig. 1. Starch yield varied according to sorghum variety and to the isolation procedure. Generally, Giza 15 had higher starch yield for both extraction procedures (Table 1) used in this study that reached to $39.24 \%$ for water isolation method and $37.57 \%$ for alkalin isolation method. In concern Assiut 14, two different procedures used for starch isolation table 1. The results in the same table showed that, both methods gave considerable amount of starch. The highest starch yield was obtained using soaking in water for two days by $33.47 \%$ starch yield followed by soaking in $(0.25 \%$ $\mathrm{NaOH}+0.025 \% \mathrm{NaHSO}_{3}$ ) yielded $28.91 \%$ starch and $(10.7 \% \mathrm{KOH}+5.25 \% \mathrm{NaOCL})$ yielded $26.81 \%, \quad(5.25 \% \mathrm{NaOCL})$ yielded $21.69 \%,(5.35 \% \mathrm{KOH}+5.25 \% \mathrm{NaOCL})$ and $\left(0.25 \% \mathrm{NaOH}+0.05 \% \mathrm{Na}_{\mathrm{H}} \mathrm{SO} 3\right)$, had nearly the same starch yield $(20.5 \%)$, and $(0.25 \%$ $\mathrm{NaOH}+0.1 \% \mathrm{Na}_{\mathrm{H}} \mathrm{SO} 3$ ) yielded $19.88 \%$ starch. The obtained results are close with those showed by Sira and Amaiz (2004), who showed that yields of starch obtained from dark and white sorghum samples ranged between 27.73 to $30.0 \%$. 
Sorour et al., : SVU-International Journal of Agricultural Sciences, 1 (1): 56-69, 2019

Table (3) Effect of different alkaline extraction on gel length and degree of syneresis of starch extract from sorghum grains

\begin{tabular}{|c|c|c|c|c|c|c|c|}
\hline \multirow{2}{*}{$\begin{array}{l}\text { Sorghum } \\
\text { Cultivars }\end{array}$} & \multirow[t]{2}{*}{ Methods } & \multicolumn{3}{|c|}{$\begin{array}{c}\text { Gel consistency } \\
\text { (length, }, \mathrm{cm})\end{array}$} & \multicolumn{3}{|c|}{$\begin{array}{c}\text { Degree of synersis } \\
\left(\mathrm{ml} \mathrm{H}_{2} \mathrm{O}\right)\end{array}$} \\
\hline & & $4 \%$ & $5 \%$ & $6 \%$ & $4 \%$ & $5 \%$ & $6 \%$ \\
\hline \multirow{8}{*}{ Assiut 14} & Control 1 & 7.4 & 10.6 & 12.2 & 24 & 21 & 14 \\
\hline & $\mathbf{1 A}$ & 6.8 & 8.1 & 12.3 & 31 & 26 & 14 \\
\hline & $1 B$ & 10.2 & 13.3 & 19.8 & 33 & 0 & 0 \\
\hline & $1 \mathrm{C}$ & 9.8 & 12.7 & 14.3 & 24 & 0 & 0 \\
\hline & Control 2 & 8.4 & 9.6 & 13.5 & 22 & 12 & 10 \\
\hline & $2 \mathbf{A}$ & 11.2 & 12 & 12 & 24 & 18 & 0 \\
\hline & $2 B$ & 10.2 & 14.3 & 15.8 & 20 & 19 & 0 \\
\hline & 2C & 10.4 & 11.6 & 13.7 & 25 & 23 & 11 \\
\hline \multirow{2}{*}{ Giza 15} & Control A & 5.1 & 7.5 & 9.3 & 25 & 22 & 10 \\
\hline & $\mathbf{A}$ & 5.4 & 8.1 & 10.1 & 29 & 22 & 0 \\
\hline \multicolumn{3}{|c|}{ Control 1= Boiling with water } & \multicolumn{5}{|c|}{$\mathbf{1 A}=$ Boiling with $\mathrm{KOH} 10.7 \%+\mathrm{NaOCl} 5.25 \%$} \\
\hline \multicolumn{3}{|c|}{$\mathbf{1 B}=$ Boiling with $\mathrm{KOH} 5.35 \%+\mathrm{NaOCl} 5.25 \%$} & \multicolumn{5}{|c|}{$\mathbf{1 C}=$ Boiling with $\mathrm{NaOCl} 5.25 \%$} \\
\hline \multicolumn{3}{|c|}{ Control 2 = Soaking in water for 2 days } & \multicolumn{5}{|c|}{$2 \mathrm{~A}=$ Soaking in $\mathrm{NaOH} 0.25 \%+\mathrm{NaHSO}_{3} 0.025 \%$ for 2 days } \\
\hline \multicolumn{3}{|c|}{ 2B $=$ Soaking 2days in $\mathrm{NaOH} 0.25 \%+\mathrm{NaHSO}_{3} 0.05 \%$} & \multicolumn{5}{|c|}{$2 \mathrm{C}=$ Soaking in $\mathrm{NaOH} 0.25 \%+\mathrm{NaHSO}_{3} 0.1 \%$ for 2 days } \\
\hline \multicolumn{3}{|c|}{ Control $\mathbf{A}=$ Soaking in water over night } & \multicolumn{5}{|c|}{$\mathbf{A}=$ Soaking in $\mathrm{NaOH} 0.25 \%$ over night } \\
\hline
\end{tabular}

\subsubsection{Gel consistency and syneresis degree of starch:}

Gel consistency of isolated sorghum (Giza 15 and Assuit 14) starch were determined by measuring the length of starch gel at different concentrations $(4,5$ and $6 \%)$ and the obtained data are shown in Table. 3 The data showed that gel made with low sorghum tannin (Giza 15) was thinnest (gels with the highest values) than that made from high tannin sorghum (Assiut 14). Giza 15 showed gel consistency values between 5.1 and 10.1 $\mathrm{cm}$, whereas the value for the Assiut 14 sample ranged between 6.8 and $19.8 \mathrm{~cm}$. These results are in the line with Chandrashekar and Kirleis (1988) they reported that the gel consistency of sorghum starch ranged from 4 to $11 \mathrm{~cm}$. Similar to the obtained results by Ahmed et al. ( 2016) who showed that the gel consistency ranged from 8.9 to $12.9 \mathrm{~cm}$ in sorghum starch.
The syneresis degrees of sorghum starch gels at different concentrations (4, 5 and 6\%) are revealed in Table (3). Results noted that there was a difference in the degrees of syneresis $\left(\mathrm{mL} \mathrm{H}_{2} \mathrm{O}\right)$ were separated from the gel of starch for sorghum starch extracted using different method at $4 \%$, while for 5 and $6 \%$ starch concentration, the degrees of syneresis of boiling with $\mathrm{KOH} 5.35 \%+\mathrm{NaOCl} 5.25 \%$ and boiling with $\mathrm{NaOCl} 5.25 \%$ treatments recorded zero by other meaning there wasn't water were separated from the gel of starch starting from 5\% starch concentrations. At the same time soaking in $\mathrm{NaOH} 0.25 \%+$ $\mathrm{NaHSO}_{3} 0.025 \%$ for 2 days, soaking in $\mathrm{NaOH} 0.25 \%+\mathrm{NaHSO}_{3} 0.05 \%$ for 2 days and boiling with $\mathrm{KOH} 10.7 \%+\mathrm{NaOCl}$ $5.25 \%$ procedures recorded zero degree of syneresis at $6 \%$ starch concentration. However for other treatments the degree of synersis ranged between 10 to 14 at $6 \%$ starch concentration. Singh et al.(2012) 
found the degree of synersis of sorghum starch ranged from 0.95 to $26.21 \mathrm{~mL} \mathrm{H}_{2} \mathrm{O}$. The syneresis degrees were $16.60,11.20$ and $0.00 \mathrm{~mL} \mathrm{H}_{2} \mathrm{O}$ in 2,4 and $6 \%$ mung bean starch gel concentrations (Abdel-Rahman et al., 2008).

Table (4) Effect of Alkaline medium extraction on gelatinization temperature of starch.

\begin{tabular}{|c|c|c|c|c|}
\hline \multirow{2}{*}{$\begin{array}{l}\text { Sorghum } \\
\text { Cultivars }\end{array}$} & \multirow{2}{*}{ Methods } & \multicolumn{3}{|c|}{ Gelatinization Temprature $(\mathcal{C}$. range } \\
\hline & & Initial & Mid & End \\
\hline \multirow{8}{*}{ Assiut 14} & Control 1 & 64 & 76 & 79 \\
\hline & $\mathbf{1 A}$ & 64 & 71 & 78 \\
\hline & 1B & 60 & 66 & 70 \\
\hline & $1 \mathrm{C}$ & 63 & 72 & 77 \\
\hline & Control 2 & 63 & 68 & 80 \\
\hline & $\mathbf{2 A}$ & 63 & 70 & 78 \\
\hline & $2 B$ & 62 & 69 & 78 \\
\hline & 2C & 62 & 68 & 75 \\
\hline \multirow{2}{*}{ Giza 15} & Control A & 60 & 68 & 76 \\
\hline & $\mathbf{A}$ & 63 & 70 & 79 \\
\hline \multicolumn{2}{|c|}{ Control 1= Boiling with water } & \multicolumn{3}{|c|}{$\mathbf{1 A}=$ Boiling with $\mathrm{KOH} 10.7 \%+\mathrm{NaOCl} 5.25 \%$} \\
\hline \multicolumn{2}{|c|}{$\mathbf{1 B}=$ Boiling with $\mathrm{KOH} 5.35 \%+\mathrm{NaOCl} 5.25 \%$} & \multicolumn{3}{|c|}{$\mathbf{1 C}=$ Boiling with $\mathrm{NaOCl} 5.25 \%$} \\
\hline \multicolumn{2}{|c|}{ Control 2 = Soaking in water for 2 days } & \multicolumn{3}{|c|}{$2 \mathrm{~A}=$ Soaking in $\mathrm{NaOH} 0.25 \%+\mathrm{NaHSO}_{3} 0.025 \%$ for 2 days } \\
\hline \multicolumn{2}{|c|}{ 2B $=$ Soaking 2days in $\mathrm{NaOH} 0.25 \%+\mathrm{NaHSO}_{3} 0.05 \%$} & \multicolumn{3}{|c|}{$2 \mathrm{C}=$ Soaking in $\mathrm{NaOH} 0.25 \%+\mathrm{NaHSO}_{3} 0.1 \%$ for 2 days } \\
\hline \multicolumn{2}{|c|}{ Control A = Soaking in water over night } & $\mathrm{A}=$ Soaking in $\mathrm{NaO}$ & ver nigh & \\
\hline
\end{tabular}

\subsubsection{Gelatinization temperature range:}

The gelatinization transition temperature $\mathrm{T}_{0}$ (onset) $\mathrm{T}_{\mathrm{p}}$ (peak) and $\mathrm{T}_{\mathrm{c}}$ (conclusion) of white and red sorghum starches are presented in Table.4 and Fig. (2). No significant differences of gelatinization temperature between white and pigmented sorghum starches were obtained. Pigmented sorghum starch showed a gelatinization temperature comparable to white sorghum starch. Results also revealed there were no differences in the gelatinization temperatures range between of pigmented sorghum starch extracted using
Results in the same Table showed that sorghum starch isolated using soaking in water for two days (Control 2) had the highest gelatinization temperature range 63$80^{\circ} \mathrm{C}$, while sorghum starch isolated with boiling in $\mathrm{KOH} 5.35 \%+\mathrm{NaOCL} 5.25 \%$ (1B) had the lowest gelatinization temperatures rang of $60.0^{\circ} \mathrm{C}-70.0^{\circ} \mathrm{C}$, on the other hand the white sorghum starch had a gelatinization temperatures rang $63-79.0^{\circ} \mathrm{C}$. These results agreement with Taylor (1992) who reported that the gelatinization temperature range, the least onset and peak gelatinization temperatures of $60{ }^{\circ} \mathrm{C}$ and $77{ }^{\circ} \mathrm{C}$ respectively, 
in sorghum starch. Similar to the obtained results by Liu and Rosentrater (2016) showed that the gelatinization temperature ranged from $68.0^{\circ} \mathrm{C}$ to $78.0^{\circ} \mathrm{C}$ in sorghum starch.

\section{Color of starch:}

The color of isolated sorghum starch under different isolation procedures are presented in Table. 5. Hunter $L^{*}$ (lightness), $a^{*}$ (red to green) and $b^{*}$ (blue to yellow) values of sorghum starches are shown, Giza 15 ranged between $\left(L^{*}=85.2\right.$ and 91.3), $\left(a^{*}=1.68\right.$ and 3.0) and $\left(b^{*}=5.28\right.$ and 8.4), while Assiut 14 ranged between $\left(L^{*}=86.46\right.$ and 89.2), $\left(a^{*}=\right.$ 0.33 and 3.3), ( $b^{*}=4.4$ and 8.32) under different extraction procedures. Not surprisingly, Giza 15 starch had the highest $L^{*}$ value (91.3) however Assiut 14 variety with pigmented testa gave a little darker starch. The extracted starches have a great clearness for both varieties. These results are it the line with that found by Beta et al.( 2001) who reported that the color of sorghum starch under extraction in alkaline solution ranged from $\left(L^{*}=75.9\right.$ to $90.5, a^{*}=0.34$ to 5.81 and $b^{*}=4.11$ to 5.47$)$. These results are in the same trend with Sira and Amaiz( 2004)they showed that the color of sorghum starch under extraction in alkaline solution were found $\left(L^{*}\right)$ value $=91.3$ after isolated using the soaking in $\mathrm{NaOH} 0.25 \%$ over night and $\left(L^{*}\right)$ value $=78.4$ after isolated by heating in distilled water at $60^{\circ} \mathrm{C}$ for $7 \mathrm{~min}$. The form of starch isolated from pigmented variety (Assiut 14) was comparable to that from white variety (Giza 15). The values of color yellowness $b^{*}$ are ranged from 4 to 8 for white and pigmented sorghum starches; they direct a leaning of color near yellow (Sira and Amaiz, 2004) found where that $b^{*}$ value was 10.1 for white sorghum and 16.5 for the pigmented sorghum

From the same Table it clears that the $a^{*}$ value for treatments, soaking in water for 2 days(control 2), soaking in $\mathrm{NaOH} 0.25 \%+$
$\mathrm{NaHSO}_{3} 0.025 \%$ for 2 days(2A), soaking 2 days in $\mathrm{NaOH} 0.25 \%+\mathrm{NaHSO}_{3} 0.05 \%$ (2B) and boiling with $\mathrm{KOH} 10.7 \%+\mathrm{NaOCl}$ $5.25 \%(1 \mathrm{~A})$ were high comparing to other treatments.

\subsubsection{Shape and size of starch granules:}

Sorghum starch granules shape and size are shown in Fig. (3) The granule starches of the two examined sorghum varieties (Giza 15 and Assiut 14) examined using scanning light microscope showed heterogeneity of shape and size, the granules were seen to be polygonal in shape and some of them had oval shape. Scanning light microscope for starch granules from Giza 15 and Assiut 14 under different extraction procedures had no significant difference in shape. Some granules showed pin holes locally at the smooth surface (Fig. 3) and the same observation was reported by Benmoussa et al., (2006),

Our results are in accordance with Sang et al. (2008); Ai et al.(2011) who reported that, the granules are mostly spherical and polygonal, with indentations and pores on the surface radial, tube-like channels of granules penetrate from the external surface into a cavity at the hilum(Huber and BeMiller, 1997). The isolated starches from tow sorghum varieties (Assiut 14 and Giza 15) using different procedures are shown in Fig. (3). The granule size of white sorghum starch (Giza 15) varies between $3 \mu \mathrm{m}$ to $15 \mu \mathrm{m}$, while the size in pigmented sorghum (Assiut 14) varies from $3.14 \mu \mathrm{m}$ to $14.78 \mu \mathrm{m}$. These results are in accordance with those reported by Benmoussa et al. (2006) and Singh et al. (2010). In the current study, starch granule size of Giza 15 exhibited not significantly difference for larger size compared to that of Assiut 14 extracted using different extraction procedures. 

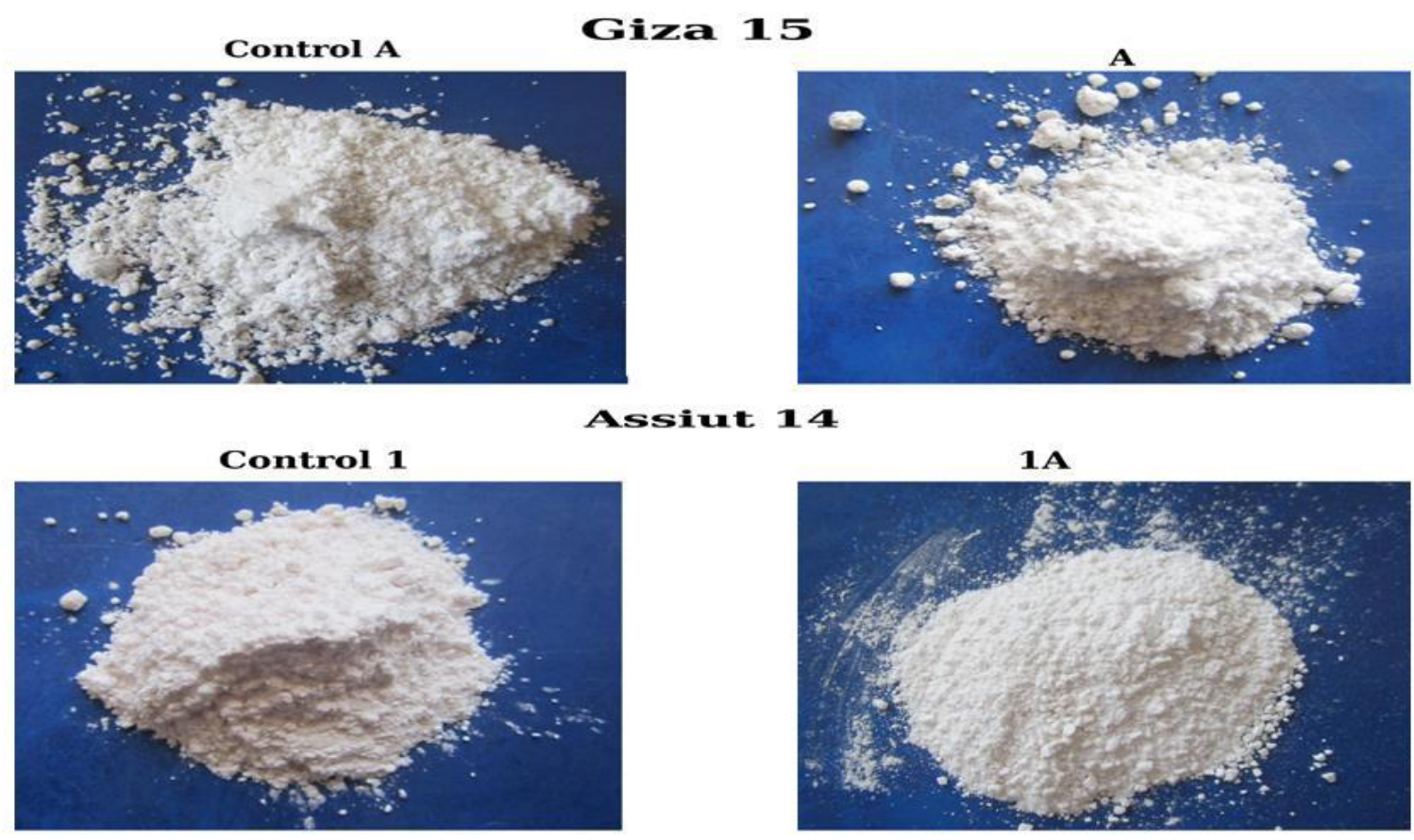

Assiut 14

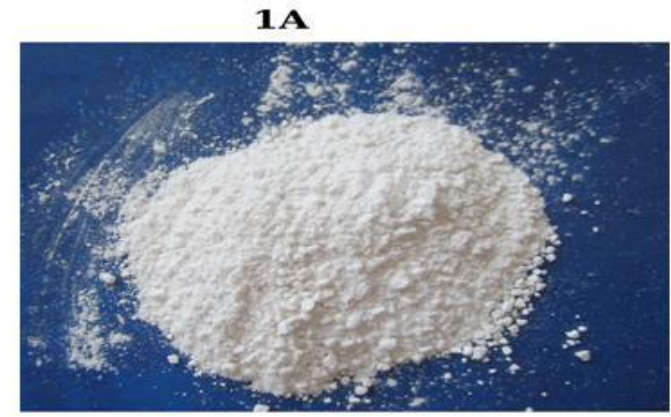

$1 \mathbf{B}$
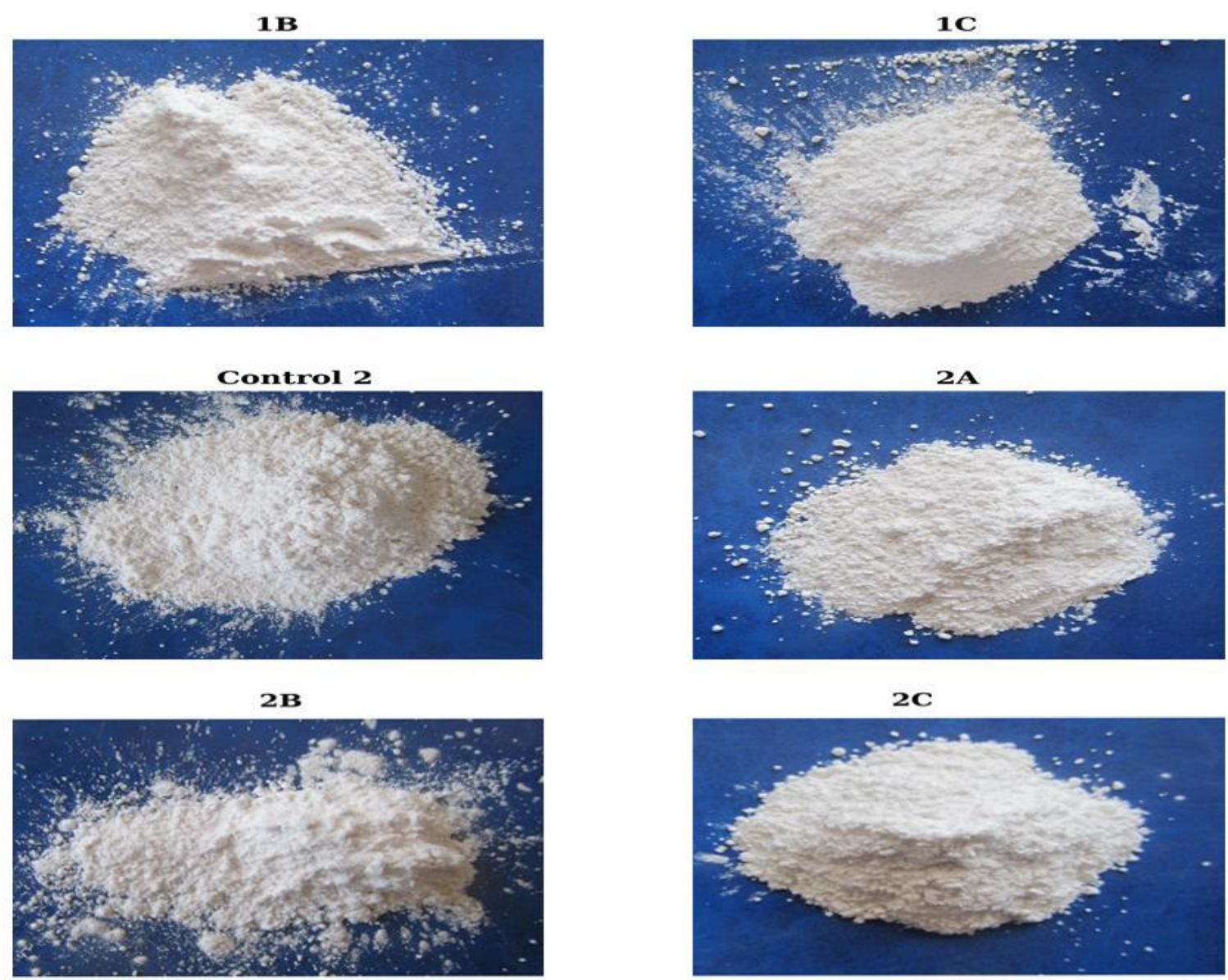

Fig ( 1 ) Effect of different extraction alkaline medium on sorghum starch isolation

Control A = Soaking in water overnight Contril 1 = Boiling with water

1B = Boiling with KOH 5.35\% + NaOCL 5.25\%

Control 2 = Soaking in water for 2 days

$2 \mathrm{~B}=$ Soaking in $\mathrm{NaOH} 0.25 \%+\mathrm{NaHSO}_{3} 0.05 \%$ for 2 days
A = Soaking in NaOH $0.25 \%$ overnight

$1 \mathrm{~A}=$ Boiling with KOH $10.7 \%$ + NaOCL $5.25 \%$

$1 \mathrm{C}=$ Boiling with NaOCL $5.25 \%$

$2 \mathrm{~A}=$ Soaking in $\mathrm{NaOH} 0.25 \%+\mathrm{NaHSO}_{3} 0.025 \%$ for 2 days

$2 \mathrm{C}=$ Soaking in $\mathrm{NaOH} 0.25 \%+\mathrm{NaHSO}_{3} 0.1 \%$ for 2 days 
Table (5) Effect of different alkaline extraction on color of starch extract from sorghum grains.

\begin{tabular}{cccccc}
\hline \multirow{2}{*}{$\begin{array}{c}\text { Sorghum } \\
\text { Cultivars }\end{array}$} & Methods & \multicolumn{3}{c}{ Color } & \multirow{2}{*}{ LSD $_{\mathbf{0 . 0 5}}$} \\
\cline { 3 - 5 } & & $\boldsymbol{L}^{*}$ & $\boldsymbol{a}^{*}$ & $\boldsymbol{b}^{*}$ & \\
\hline & Control 1 & $89.2 \pm 0.68$ & $0.43 \pm 0.1$ & $7.8 \pm 0.6$ & \\
& $\mathbf{1 A}$ & $87.1 \pm 0.5$ & $0.33 \pm 0.04$ & $4.4 \pm 0.52$ & \multirow{2}{*}{$\mathbf{0 . 6 5}^{*}$} \\
& $\mathbf{1 B}$ & $86.75 \pm 0.01$ & $0.34 \pm 0.12$ & $8.32 \pm 0.43$ & \\
Assiut 14 & $\mathbf{1 C}$ & $87.2 \pm 0.02$ & $0.67 \pm 0.12$ & $7.3 \pm 0.18$ & \\
& Control 2 & $84.37 \pm 0.65$ & $3.3 \pm 0.13$ & $6.26 \pm 0.83$ & \\
& $\mathbf{2 A}$ & $87.46 \pm 0.22$ & $2.7 \pm 0.23$ & $5.6 \pm 0.28$ & \multirow{2}{*}{$\mathbf{0 . 6 5}^{*}$} \\
& $\mathbf{2 B}$ & $86.53 \pm 53$ & $2 \pm 0.055$ & $6.5 \pm 0.14$ & \\
& $\mathbf{2 C}$ & $87.8 \pm 0.39$ & $1.12 \pm 0.00$ & $6.64 \pm 0.23$ & \\
Giza 15 & Control A & $85.2 \pm 0.9$ & $3 \pm 0.86$ & $8.4 \pm 0.47$ & \multirow{2}{*}{$\mathbf{1 . 2}^{*}$} \\
& $\mathbf{A}$ & $91.3 \pm 0.6$ & $1.68 \pm 0.015$ & $5.28 \pm 0.33$ & \\
\hline
\end{tabular}

Control 1= Boiling with water

$\mathbf{1 B}=$ Boiling with $\mathrm{KOH} 5.35 \%+\mathrm{NaOCl} 5.25 \%$

Control 2 = Soaking in water for 2days

2B $=$ Soaking 2days in $\mathrm{NaOH} 0.25 \%+\mathrm{NaHSO}_{3} 0.05 \%$

Control A = Soaking in water over night

$\boldsymbol{L}^{*}=$ lightness $\quad a^{*}=$ red to green $\quad b^{*}=$ blue to yellow

$$
\begin{aligned}
& \mathbf{1 A}=\text { Boiling with } \mathrm{KOH} 10.7 \%+\mathrm{NaOCl} 5.25 \% \\
& \mathbf{1 C}=\text { Boiling with } \mathrm{NaOCl} 5.25 \% \\
& \mathbf{2 A}=\text { Soaking in } \mathrm{NaOH} 0.25 \%+\mathrm{NaHSO}_{3} 0.025 \% \text { for } 2 \text { days } \\
& \mathbf{2 C}=\text { Soaking in } \mathrm{NaOH} 0.25 \%+\mathrm{NaHSO}_{3} 0.1 \% \text { for } 2 \text { days } \\
& \mathbf{A}=\text { Soaking in } \mathrm{NaOH} 0.25 \% \text { over night }
\end{aligned}
$$

Gaffa et al. (2004) noticed that the higher amount of large molecules was shown from red sorghum comparing with the white sorghum starch. Boudries et al. (2014) found that the starch granule size varied between 6.33 and $39.91 \mu \mathrm{m}$ for whit sorghum and varied from 7.10 to $44.78 \mu \mathrm{m}$ for pigmented sorghum, size was nearly similar to those of corn and cassava.

\section{Discussion}

\subsection{Properties of starch isolated by different alkaline medium:-}

\subsubsection{Starch yield:}

The low yield of sorghum starch obtained in this study may be explained through extraction step, (filtering), that may cause the major mass loss in starch in all extraction procedures

\subsubsection{Gel consistency and degree of syneresis of starch:}

It is well known that gel consistency depends on some factors such as amylose content of sorghum, protein content, cell wall composition, and degradation enzymes. Ahmed et al. (2016) showed that thehighest values for gel consistency of sweet sorghum varieties compared with grain ones attributed to amylose content, further more Beta et al. (2001) noticed that the gel hardness was mainly controlled by the amylose content of starch. The participation of protein in limiting starch gelatinization in germinated sorghums and thus producing thinner gels (Elkhalifa and Bernhardt, 2013). The grain modification during germination is mainly due to the action of cell wall degradation enzymes such as $\beta$-glucanase and proteases, which support the breakdown of protein matrix. The matrix protein in sorghum is 
intimately bound to the endosperm cell walls and he phenolic compounds play a role in this attachment (Glennie, 1984; Parker et al., 1999).This study assumed that the content of phenolic compounds and the nature of these compounds for both sorghum varieties studied in addition to the differences in endosperm cell wall could be attributed to those differences of gel consistency made of Giza 15 and Assiut 14.

The degrees of syneresis of sorghum starch were decedent by increasing of starch concentration. The results suggested that the chemical treatment of sorghum grains could cause cell wall change and starch characteristics as associated. It may be of relevance to the findings of Glennie (1984) who indicated that the matrix protein in sorghum is intimately bound to the endosperm cell walls.

\subsubsection{Gelatinization temperature range:}

The starch gelatinization is measured by loss of granule birefringence in dilute granule suspensions exposed to an increased temperature. The temperature at which $95 \%$ of the starch granules lose birefringence is the birefringence endpoint temperature. The relative amount of gelatinized versus native starch granules determined by microscopic technique (Guiné and dos Reis Correia, 2013). Congo red dye test used to distinguish between native and gelatinized and damaged starch illustrated the gelatinization temperatures of sorghum starch granules examined under scanning light microscope. Gelatinization at high temperature can be an indication for the higher stability of starch crystallites in starch molecules.

\subsubsection{Color of starch:}

Color is an important measure for starch quality, and the starch paste should be clear and free from any off-color for better acceptability. The polyphenol content and the kernel structure of sorghum were attributed to starch properties. A white pericarp, with no pigments, is vitally important to lower color in tannin-free sorghum used for white starch production. The polyphenolic compounds of Giza 15 could become adsorbed to the starch during wet milling. The starch of pigmented sorghum extracted by boiling had low $a^{*}$ value, that could be as a results of the bleach effect of sodium hypochlorite.

The result in this study suggests that both sorghum varieties and the used isolation procedures had less yellow color and less remaining rate of protein and lipids too, by other meaning, grain pericarp, color, presence or absence of pigmented testa, and polyphenol content did not relate to the pink color of isolated sorghum starches. Therefore the isolated starch from pigmented sorghum could substitute that of white sorghum in food industry.

\subsubsection{Shape and size of starch granules:}

Sorghum starch existed in plant tissues in the form of granules whose characteristics of size, shape and form were distinctive to each botanical specie starch heterogeneity could be caused by the difference in developing environment or in genetic characteristic. The floury endosperm has more rounded starch granules whereas in the horny endosperm the angular granules are the predominant Boudries et al. (2014). Therefore our results assumed that the endosperm in the examined sorghum varieties could be with horny endosperm and with high content of amylose. The pin holes appeared due to the action of amylases during the growth of sorghum grains or the starch isolation process (Takeda et al., 1989). The amylase content increase the irregularity of starch granule shape also increased (Wang et al., 1993). 


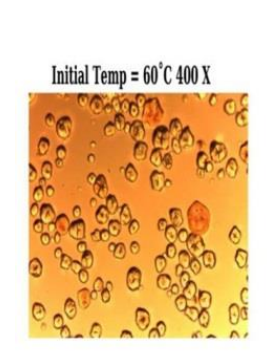

\section{Giza 15 Control A}

Mid Temp $=68^{\circ} \mathrm{C} 400 \mathrm{X}$

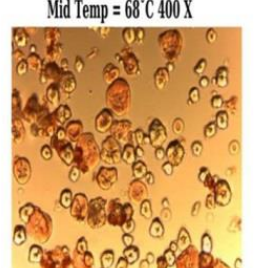

End Temp $=75^{\circ} \mathrm{C} 400 \mathrm{X}$

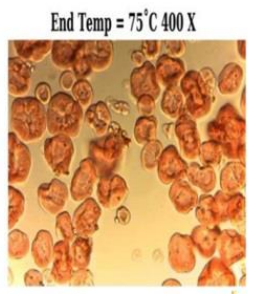

Giza $15 \mathrm{~A}$
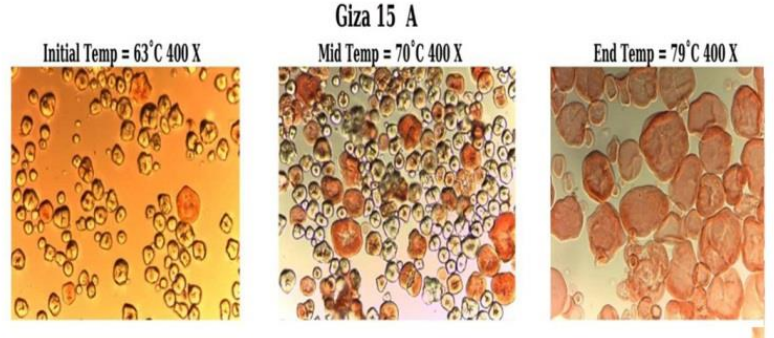

Assiut 14 Control 1

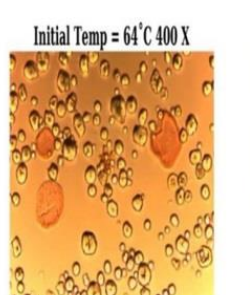

8.00000000

$2023.9000 .2)^{\circ}$
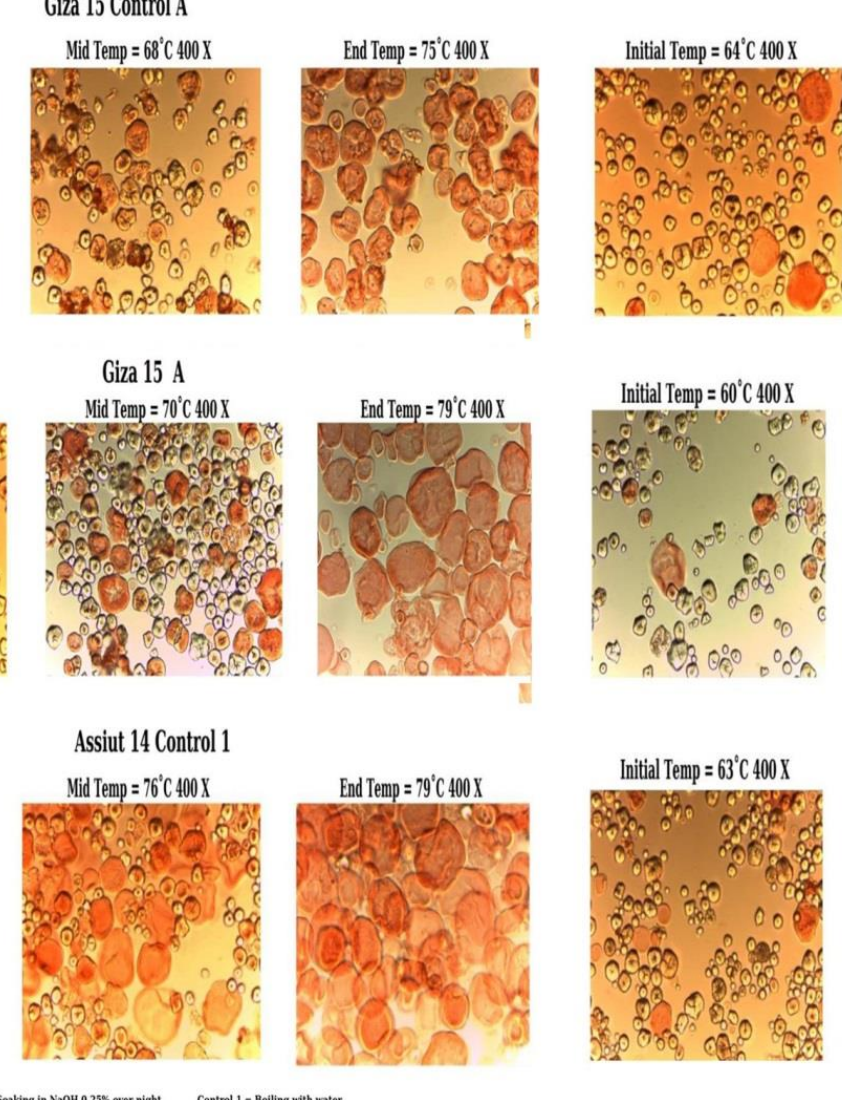

Assiut $141 \mathrm{~A}$
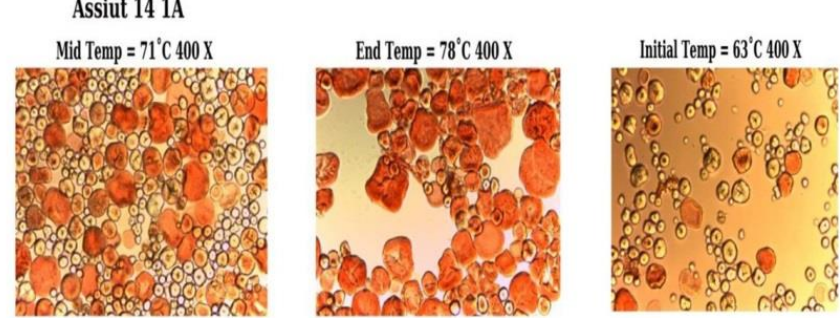

Assiut $142 \mathrm{~A}$

Mid Temp $=70^{\circ} \mathrm{C} 400 \mathrm{X}$

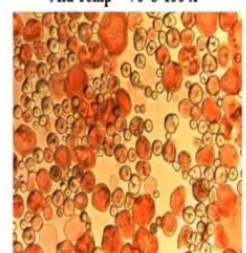

Assiut 14 1B

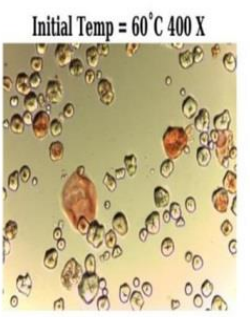

Mid Temp $=66^{\circ} \mathrm{C} 400 \mathrm{X}$

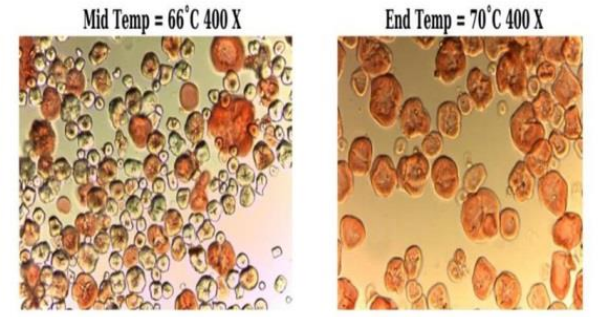

Assiut $141 \mathrm{C}$

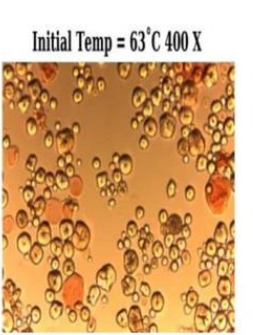

Mid Temp $=72^{\circ} \mathrm{C} 400 \mathrm{X}$
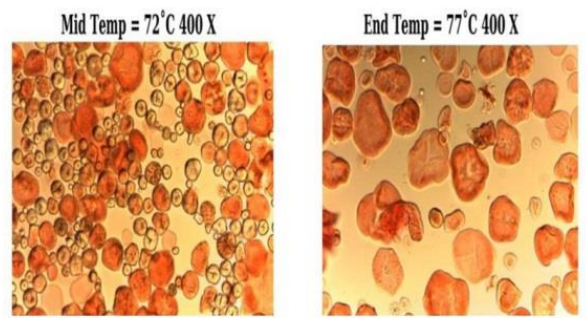

Assiut 14 Control 2

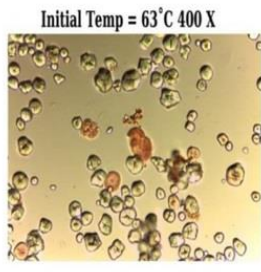

Mid Temp $=68^{\circ} \mathrm{C} 400 \mathrm{X}$
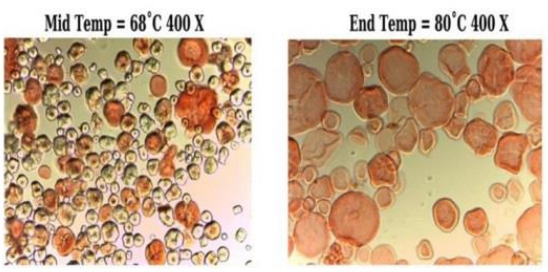

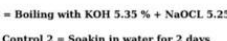

1c - Bolling with Naocc s.2.25\%

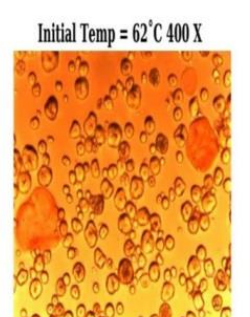

Assiut 14 2B
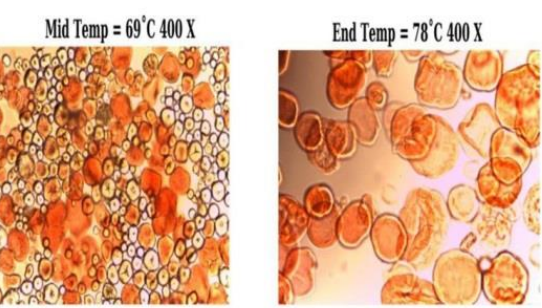

Assiut $142 \mathrm{C}$

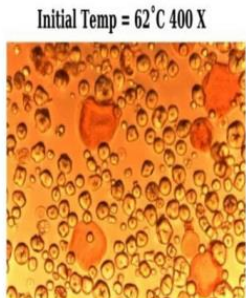

Nid Temp $=68^{\circ} \mathrm{C} 400 \mathrm{X}$

End Temp $=75^{\circ} \mathrm{C} 400 \mathrm{X}$
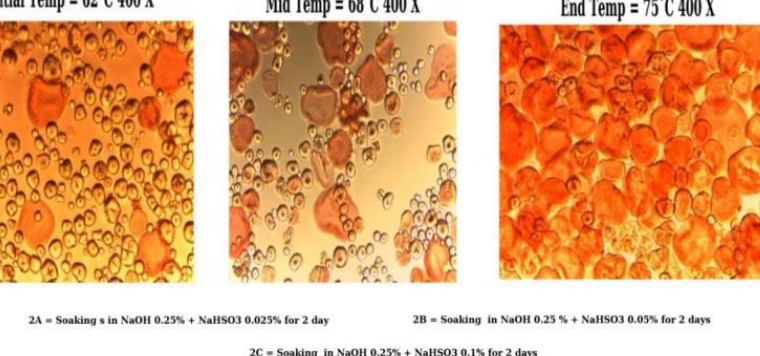

Fg(2) Effect of Alkaline medium extraction on gelatinization Temperature. of starch 


\section{Conclusions}

The examined sorghum varieties are good source of starch, pigment sorghum variety underwent to the alkaline extraction procedures produced starch with good quality that was comparable to those of white sorghum. Therefore, the isolated starch from both verity could use efficiently in food applications.

\section{Acknowledgement}

The authors gratefully acknowledge Dr. Mahmoud Sabry, Geology Department, Faculty of Science, South Valley University, for his excellent support in the laboratory analysis as well as for Dr. Amir Alsaman, Agriculture Research Centre, Shandaweel, Egypt for generous assistance and providing the martials during the study.

\section{Declarations}

The authors declare that they have no conflicts of interests.

\section{REFERENCES}

Abdel-Rahman, E.S.A., El-Fishawy, F.A., El-Geddawy, M.A., Kurz, T. and ElRify, M.N. (2008) 'Isolation and physico-chemical characterization of mung bean starches', International journal of food engineering, 4(1).

Ahmed, A.M., Zhang, C. and Liu, Q. (2016) '

Comparison of Physicochemical characteristics of starch isolated from sweet and grain sorghum', Journal of Chemistry, 2016.

Ai, Y., Medic, J., Jiang, H., Wang, D. and Jane, J.L. (2011) 'Starch characterization and ethanol production of sorghum', Journal of agricultural and food chemistry, 59(13), pp.73857392.

Benmoussa, M., Suhendra, B. (2006)

'Distinctive sorghum starch granule morphologies appear to improve raw starch digestibility', Starch, Stärke, 58(2), pp.92-99.

Beta, T., Corke, H., Rooney, L.W. and Taylor, J.R.N. (2001) ' Starch properties as affected by sorghum grain chemistry', Journal of the Science of Food and Agriculture, 81(2), pp.245251.

Boudries, N., Nadjemi, B., BelhanecheBensemra, N. and Sindic, M. (2014) 'Morphological and thermal properties of starches isolated from white and pigmented sorghum landraces grown in hyper arid regions', Journal of Agricultural Science and Technology, 4, pp.674-682.

Boudries, N., Belhaneche, N., Nadjemi, B., Deroanne, C., Mathlouthi, M., Roger, B. and Sindic, M. (2009) 'Physicochemical and functional properties of starches from sorghum cultivated in the Sahara of Algeria', Carbohydrate Polymers, 78 (3), pp.475480.

Chandrashekar, A. and Kirleis, A.W. (1988) 'Influence of protein on starch gelatinization in sorghum', Cereal Chem, 65(6), pp.457-462.

Elkhalifa, A.E.O. and Bernhardt, R. (2013) ' Some physicochemical properties of flour from germinated sorghum grain', Journal of food science and technology, 50(1), pp.186-190.

FGIS-GIPSA. (2006) 'The official United States Standards for grain. Federal Grain Inspection Service, Inspection Division', U.S. Department of 
Agriculture, Washington, DC' An Open Access Journal published by ICRISAT

Gaffa, T., Yoshimoto, Y., Hanashiro, I., Honda, O., Kawasaki, S. and Takeda, Y. (2004) ' Physicochemical properties and molecular structures of starches from millet (Pennisetum typhoides) and sorghum (Sorghum bicolor L. Moench) cultivars in Nigeria', Cereal chemistry, 81(2), pp.255-260.

Giese, J.A.M.E.S. (2000) 'Color measurement in foods as a quality parameter', Food Technology,54(2), pp.62-63.

Glennie, C.W. (1984) ' Endosperm cell wall modification in sorghum grain during germination' Cereal Chemistry.

Guiné, R. D. P. F., and dos Reis Correia, P. M. (2013) 'Engineering aspects of cereal and cereal-based products' $C R C$ Press. page, 261.

Delcour, J.A. and Hoseney, R.C. (2010) 'Principles of cereal science and technology' St. Paul, MN, USA: AACC International.

Hoseney, R. C., Varriano-Marston, E. and Dendy, D.AV. (1981) 'Sorghum and millet. In Y. Pomeranz (Ed.), Advances in cereal science (vol. IV)' St. Paul, MN: American Association of Cereal Chemis AACC.

Huber, K.C. and BeMiller, J.N. (1997) 'Visualization of channels and cavities of corn and sorghum starch granules', Cereal Chemistry, 74(5), pp.537-541.

Jane, J.L. (1993) 'Mechanism of starch gelatinization in neutral salt solutions', Starch Stärke, 45(5), pp.161-166.

Kaur, L., Singh, J., McCarthy, O.J. and Singh, H. (2007) 'Physico-chemical, rheological and structural properties of fractionated potato starches', Journal of Food Engineering, 82(3), pp.383-394.
Liu, K. and Rosentrater, K.A. (2016) 'Distillers grains: Production, properties, and utilization' AOCS Publishing.

Matsuki, J., Yasui, T., Kohyama, K. and Sasaki, T. (2003) ' Effects of environmental temperature on structure and gelatinization properties of wheat starch' Cereal Chemistry, 80(4), pp.476-480.

Parker, M. L., Grant, A., Rigby, N. M., Belton, P. S., and Taylor, J. R. N. (1999) ' Effects of popping on the endosperm cell walls of sorghum and maize' Journal of Cereal Science, 30(3), 209-216.

Perez, E., Bahnassey, Y.A. and Breene, W.M. (1993) 'A simple laboratory scale method for isolation of amaranth starch', Starch-Stärke, 45(6), pp.211214.

Ratnayake, W.S., Wassinger, A.B. and Jackson, D.S. (2007) 'Extraction and characterization of starch from alkaline cooked corn masa', Cereal chemistry, 84(4), pp.415-422.

Sang, Y., Bean, S., Seib, P. A., Pedersen, J., and Shi, Y.C. (2008) 'Structure and functional properties of sorghum starches differing in amylose content', Journal of agricultural and food chemistry, 56(15), 6680-6685.

Singh, H., Singh Sodhi, N. and Singh, N. (2009) 'Structure and Functional Properties of Acid Thinned Sorghum Starch' International Journal of Food Properties 12: 713-725.

Singh, H., Sodhi, N. S., and Singh, N. (2010) 'Characterisation of starches separated from sorghum cultivars grown in India', Food chemistry, 119(1), 95-100.

Singh, H., Sodhi, N.S. and Singh, N. (2012) 'Structure and functional properties of acetylated sorghum starch' 
Sorour et al., : SVU-International Journal of Agricultural Sciences, 1 (1): 56-69, 2019

International Journal of Food

Properties, 15(2), 312-325.

Sira, E.E.P., and Amaiz, M. L. (2004) 'A laboratory scale method for isolation of starch from pigmented sorghum' ' Journal of food engineering, 64(4), 515519.

Subramanian, V., Hoseney, R.C., and Bramel-Cox, P. (1994) 'Factors Affecting the Colour and Appearance of Sorghum Starch' Cereal Chemistry 71: 275-278.

Takeda, Y., Takeda, C., Suzuki, A., and Hizukuri, S. (1989) 'Structures and properties of sago starches with low and high viscosities on amylography' Journal of Food Science, 54(1), 177182.

Taylor, J. R. N. (1992) 'Mashing with malted grain sorghum' J. Am. Soc. Brew. Chem, 50(1), 1-34. 